\title{
THE GREEN DEAL POLICY FOR RENEWABLE ENERGY: A BIBLIOMETRIC ANALYSIS
}

\author{
Yevheniia Ziabina and Tetyana Pimonenko
}

\begin{abstract}
The industry attention to the environment has been reducing lately, leading to irreversible climate change, reaching the limit of mining, and critical indicators of $\mathrm{CO} 2$ emissions. That is why the EU has launched a new Green Policy which includes strategic directions for energy efficiency and which is expected to restore biodiversity and slow down the pace of climate change. Thus, on December 11, 2019, there was held the presentation of the "European Green Course", the main targets of which are to increase the level of energy saving by creating closed cycles in the economy; to minimize greenhouse gas emissions by 2050; to form biodiversity and climate neutrality. Accordingly, countries that accept the terms of the green deal policy need to review all aspects of their economy, from energy production to food consumption, from industry to transport and construction. The purpose of the article is to analyse publications in order to identify public's awareness of radical changes in economic and ecological spheres. The article provides a bibliometric analysis of research in the field of green deal policy, energy conservation and energy efficiency through the introduction of renewable energy sources. The authors selected 337 papers which were published in 19992019. Scopus provided the database for analysis. By means of VOSviewer the results of bibliometric analyses were visualized in a definitions map. It allowed identifying six clusters that combine 131 terms. As a result of the research, the connection between the terms renewable energy sources and energy saving - was revealed with the help of the constructed bibliographic map.
\end{abstract}

Keywords: green economy, green deal policy, renewable energy sources, energy saving, energy modernization, energy security, carbon-neutral economy

JEL Classification: Q42 


\section{Authors:}

\section{Yevheniia Ziabina}

Sumy State University, Sumy, Ukraine

E-mail:e.ziabina@econ.sumdu.edu.ua

https://orcid.org/0000-0003-0832-7932

\section{Tetyana Pimonenko}

Sumy State University, Sumy, Ukraine

E-mail: tetyana_pimonenko@econ.sumdu.edu.ua

https://orcid.org/0000-0001-6442-3684

Citation: Ziabina, Ye., \& Pimonenko, T. (2020). The Green Deal Policy for Renewable Energy: A Bibliometric Analysis. Virtual Economics. 3(4), 147-168. https://doi.org/10.34021/ve.2020.03.04(8) 


\section{Introduction}

After the tragic radiation accident on March 11, 2011 at the Fukushima-1 nuclear power plant (Japan), which became the largest accident in the nuclear power industry after the Chernobyl accident (1986), almost all countries reconsidered their priorities in the energy sector and began to carry out reforms on modernization and re-profiling of energy production. The most prospective directions were alternative energy sources and the transition to a carbon-neutral economy. For example, the EU countries have agreed on the Energy Efficiency Action Plan for 2007-2020 (Verkhovna Rada of Ukraine, 2006), which is a 20-20-20 Plan to reduce $\mathrm{CO}_{2}$ emissions by $20 \%$, to increase energy efficiency by $20 \%$ and to increase the share of renewable energy sources in the energy sector by $20 \%$. Ukraine's plans at this stage are to reach $11 \%$ of renewable energy sources in the structure of final energy consumption and increase the level of energy saving by $9 \%$. At the same time, Ukraine, which has acceded to the Paris Climate Agreement, has set a goal - to reduce $\mathrm{CO}_{2}$ emissions by $40 \%$ by 2030 as compared to 1990 (Verkhovna Rada of Ukraine, 2016).

But taking into account that almost all partner countries have met the targets by 2020, strong investment potential and opportunities of the EU allowed not stopping at the first successes, and in mid-2019 the European Commission announced a new European Green Deal (European Commission, 2020), which was presented on December 11, 2019. The European Green Deal covers all sectors of the economy and consists of eight main strategic targets: a climate ambition (Formation and development of the "Climate Law"); clean, affordable and secure energy (Regulation of the energy sector and development of the smart sector integration); an industrial strategy for a clean and circular economy (the EU industry reform); a sustainable and smart mobility (encouragement of the alternative fuels production, development of infrastructure for cars running on alternative fuels); greening the Common Agricultural Policy/a "Farm to Fork" Strategy (development of the measures to ban the use of inorganic fertilizers and pesticides in farming); preserving and protecting biodiversity (measures to protect forests and biodiversity); towards a zero-pollution ambition for a toxic free environment; mainstreaming sustainability in all the EU policies (European Commission, 2020).

The European Green Deal is a roadmap for the transition to a carbon-neutral economy, taking into account the competitiveness of a clean economy and sustainable development, living standards and health. The main goal of the green policy is economic growth decoupled from the resource use.

Achieving the ambitious results of the European Green Deal is not possible without all countries' participation, because the climate change and $\mathrm{CO}_{2}$ emissions are global in nature, and solving these problems on one continent will not be of much benefit to the whole world. That is why the EU campaigns all countries for joining the Green Agreement and developing economic relations on equal competitive conditions. 
In January 2020, Ukraine supported the EU initiative and agreed to cooperate in the areas of decarbonisation of the environment and become an integral part of the European Green Deal.

\section{The Literature Review}

Nowadays, a large number of scientific papers are devoted to studying the feasibility of introducing renewable energy sources in the context of energy conservation and energy security of the country.

A large number of articles (Ziabina, 2016; Dkhili, 2018; Lyulyov et al., 2015; Bilan et al., 2019; Palienko \& Lyulyov, 2018) are devoted to the theoretical analysis of the "green" economy and macro- and micro-indicators that affect its sustainable development.

In the scientific works by (Bigerna et al., 2019; Prokopenko et al., 2017; Cebula \& Pimonenko, 2015; Yevdokimov et al., 2018; Bogachov et al., 2020; Boiko et al., 2019; Czyżewski et al., 2019; Chygryn et al. 2020; Dalevska et al., 2019; Dementyev \& Kwilinski, 2020; Drozdz et al., 2019; 2020; Dzwigol, 2019a; 2019b; 2020a; 2020b; 2020c; Dzwigol \& Wolniak, 2018; Dzwigol \& Dźwigoł-Barosz, 2018; 2020; Dzwigol et al., 2019a; 2019b; 2019c; 2020a; Furmaniak et al., 2018; 2019a; 2019b; Kharazishvili et al., 2020; Kondratenko et al., 2020; Kuzior et al., 2020; Kwilinski, 2017; 2018a; 2018b; 2018c; 2018d; 2019; Kwilinski et al., 2019a; 2019b; 2019c; 2019d; 2019e; 2019f; 2019g; 2020a; 2020b; 2020c; 2020d; Kwilinski \& Kuzior, 2020; Kyrylov et al., 2020; Lakhno et al., 2018; Lyulyov \& Pimonenko, 2017; Miskiewicz, 2017a; 2017b; 2018; 2020; Miśkiewicz \& Wolniak, 2020; Pająk et al., 2016; 2017; Pimonenko \& Lyulyov, 2018; Pimonenko et al., 2018; Prokopenko \& Miśkiewicz, 2020; Saługa et al., 2020; Savchenko et al., 2019; Tkachenko et al., 2019a; 2019b; 2019c; 2019d; 2019e; Yelnikova \& Miskiewicz, 2020), special attention is paid to sustainable development in the context of promoting renewable energy sources and digitalizing processes in the EU. Namely, the introduction of carbonneutral development taking into account the potential economic, climatic and social opportunities of each region in combination with the EU environmental policy.

The articles by (Pimonenko et al., 2018a; Lyulyov et al., 2015; Vanickova, 2020; Chygryn et al., 2018) consider the essence of green investing as one of the effective methods of developing a carbon-neutral economy in Ukraine and in the world as a whole. They distinguish such a notion as "greenwashing" and its features in the field of marketing communications in the green investment development.

The works by (Chygryn, 2018; Matsenko et al., 2011) consider the main tendencies of global consumption, including "green" consumption as a systemic and holistic approach that influences the development of renewable energy sources in the world.

The article by (Chel, 2009) "Building Integrated Renewable Energy Technologies: Embodied Energy, Economic Analysis and Potential of $\mathrm{CO}_{2}$ Emission Mitigation" reveals the main directions of increasing energy efficiency and energy conservation through introducing solar photovoltaic panels, heating devices, wind turbines, etc. 
Sineviciene Lina, Sotnyk Iryna, Kubatko Oleksandr (Sineviciene et al., 2017) analysed in their study the terms "energy efficiency" and "energy consumption" in Eastern Europe of 19962013. According to their study results, the dependence of the GDP level on energy efficiency and energy consumption was established.

In a scientific study, (Wiginton et al., 2010; Lyulyov \& Shvindina, 2017) prove the relevance of solar photovoltaic technology and present a developed five-stage model for assessing the photoelectric potential of the roof of a house, taking into account geographical, climatic and technical aspects.

The article "Minimising Carbon Footprint of Regional Biomass Supply Chains» (Lam et al., 2010) presented a regional approach targeting energy-oriented demand, which is used to assess possible ways to transferring energy from renewable sources to consumers in the certain region.

Publications concerning the countries with underdeveloped energy systems, including African countries, should also be considered. Africa today can become a global hub in "green» energy given the continent's natural potential. Thus, the study «Energy and Sustainable Development in Nigeria: The Way Forward" (Oyedepo, 2012) presents the relation between energy supply and socio-economic development of the country. The article reveals the main problems associated with frequent power outages, especially in remote areas, as well as environmental problems with the use of fossil fuels for energy.

John-Felix K. Akinbami presents the main obstacles to producing renewable energy sources and provides recommendations for optimal and consistent transition to alternative energy supply in terms of reducing $\mathrm{CO}_{2}$ emissions and economic growth and development (John-Felix, 2001).

It is also worth noting the research (Akinwale et al., 2014) based on opinion polls related to understanding the Nigerian population in the relevance and feasibility of introducing renewable energy sources. The results also show that the population is willing to pay more for electricity on the condition of an uninterrupted supply.

\section{Methods}

The search for relevant information for bibliometric analysis took place in several successive stages (Figure 1).

In the first step, shown in Figure 1, the search query in the Scopus database using the "AND" command consisted of such key basic concepts as "renewable energy sources" and "energy conservation" in the "title, abstract, keywords" category. The number of results obtained at this stage was 896 scientific sources. 
For the clarity of this study, in the second stage of this array of information the scope of research was narrowed to the following scientific domains: "Economics, Econometrics and Finance," "Multidisciplinary," "Business, Management and Accounting," "Social Sciences." The number of documents received at the end of the second stage was 337, which reveals the problems of energy efficiency and the use of renewable energy sources in the economic and social spheres. All data were saved and processed using the Excel software.

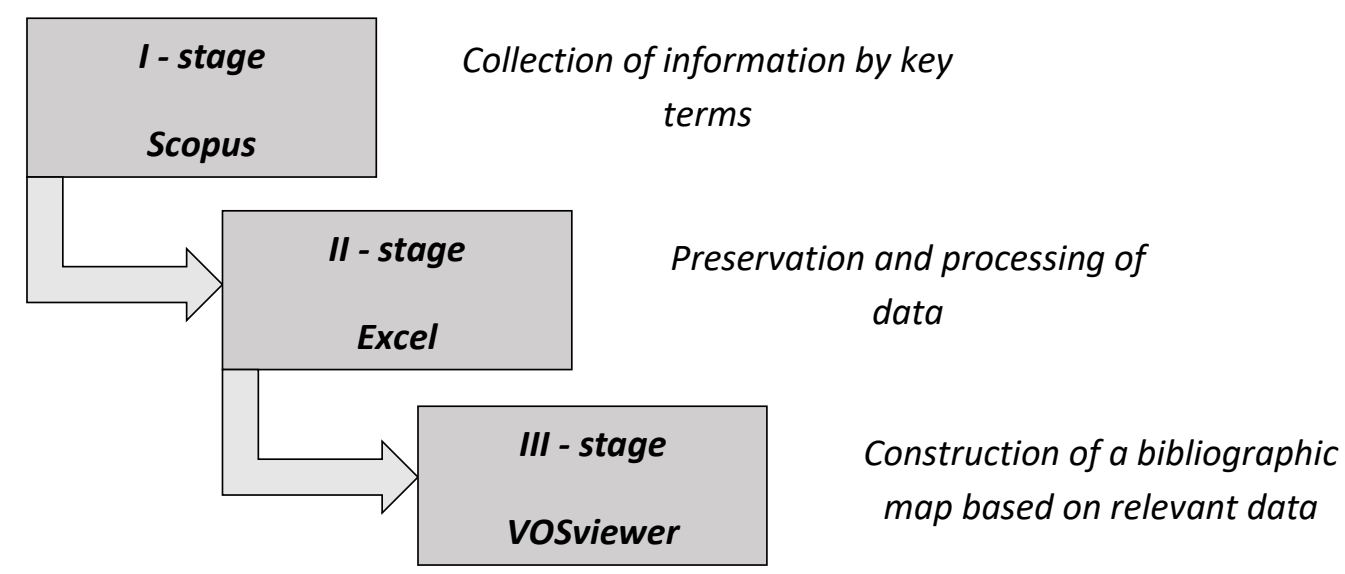

Figure 1. The Stages of Bibliometric Research

Source: developed by the authors.

In the third stage, a bibliographic map based on the relevant Scopus data was constructed using the VOSviewer research visualization and clustering analysis tool. VOSviewer is a software designed to build and visualize bibliometric links.

The bibliometric analysis using VOSviewer made it possible to identify 131 out of 2483 keywords, which corresponds to the threshold and the minimum number of occurrences in the title, keywords and abstract -5 .

\section{Results and Discussion}

In the course of information processing, there was a growing interest in researching the implementation of renewable energy sources, and improving energy efficiency. Figure 2 shows the results of the publishing activity analysis in a particular direction.

The results of the analysis show that, compared to 2009, in 2018 the number of scientific publications increased almost fourfold. According to the constructed trend line, it can be noted that the rapid growth of publishing activities on the selected topic has increased significantly since 2012, due to the active work of many countries in the direction of converting the energy sector to renewable energy sources and reducing nuclear and fuel energy to a minimum and reduction of $\mathrm{CO}_{2}$ emissions. 


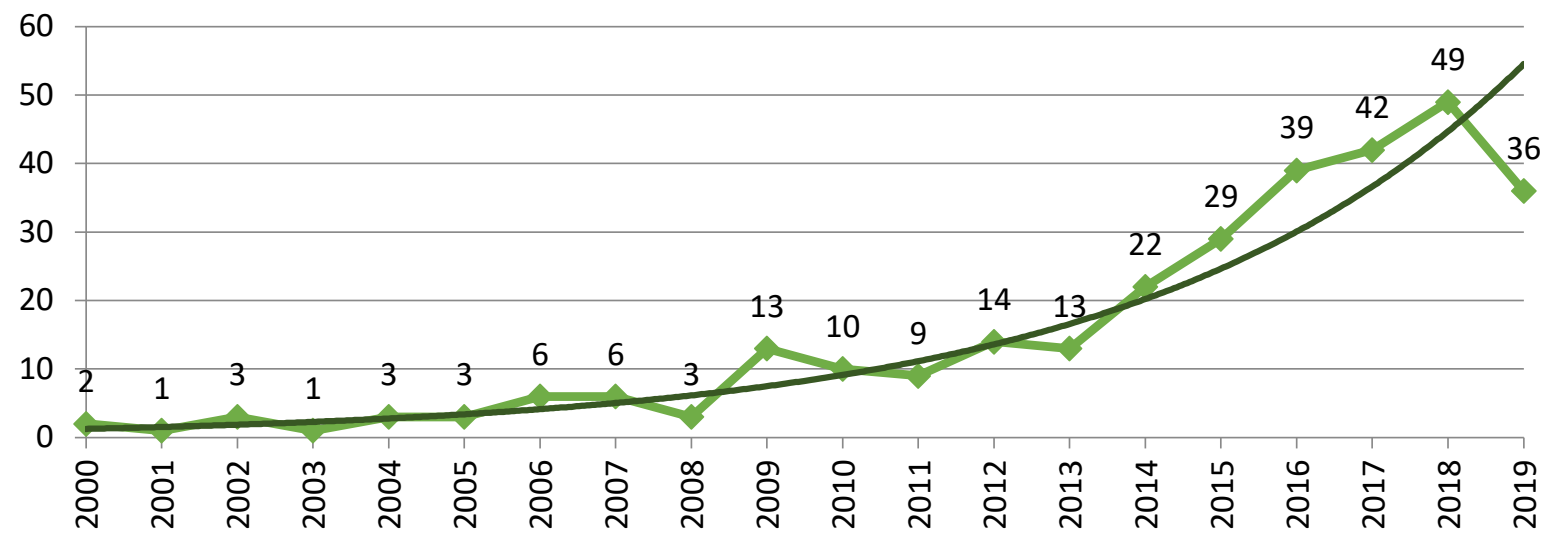

Figure 2. The Dynamics of Published Documents in the Period of 2000-2019 Sources: developed by the authors based on Scopus (2020).

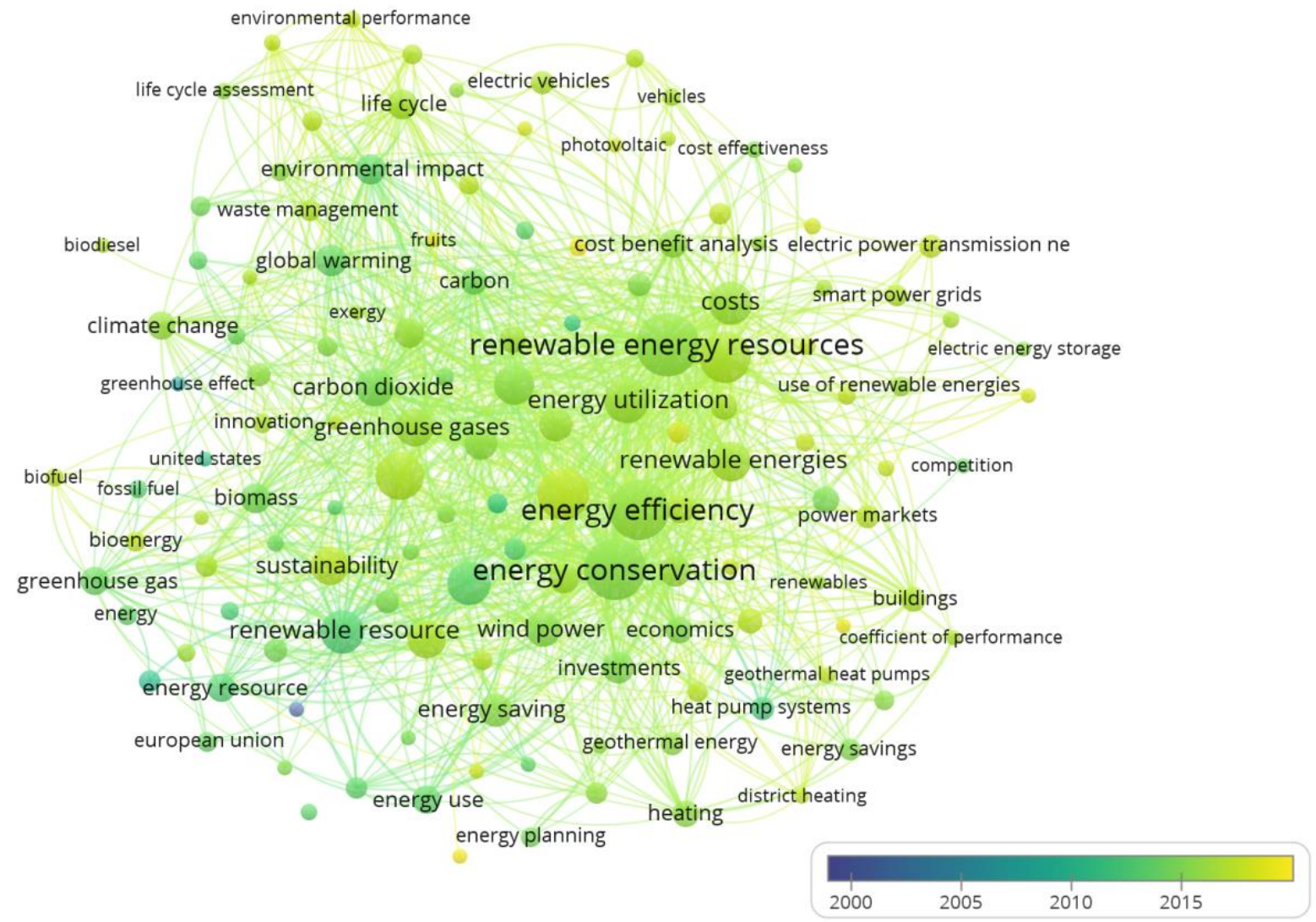

Figure 3. A Bibliometric Map of the Keywords in the Investigated Articles (2000-2019). Source: developed by the authors based on VOSviewer (2020). 
From the constructed bibliographic map (Figure 3) it is possible to note a certain evolution vector of the research urgency in the field of developing renewable energy sources. In the period of 2015-2017, scientists actively began to study issues of energy conservation, energy efficiency, alternative energy sources, global warming, neutral carbon economy, etc. It was during this period that the EU countries announced the first successful effects of the Directive 2009/28/EC adopted by the European Parliament and of the Council as of 23 April 2009 on promoting the use of energy from renewable sources in developing renewable energy sources due to the use of energy-saving technologies in the household and industry (LIGAZAKON, 2009).

During the established period of time (2000-2020) the results of research on renewable energy sources and energy conservation were published: articles -237 , conference papers -55 , book chapters -24 , reviews -13 , books -2 , and etc. The results of scientific works have been tested in more than 60 professional publications - Journal of Cleaner Production (42), Sustainability Switzerland (23), International Journal of Energy Economics and Policy (16) Sustainable Cities and Society (11), International Conference on the European Energy Market Eem (8) etc. Figure 4 shows twenty countries with the largest number of published research examining the problems of energy saving and energy efficiency in implementing renewable energy sources in the field of "Economics, Econometrics and Finance», "Multidisciplinary», "Business, Management and Accounting», "Social Sciences» from 2000 to 2019 to the Scopus database.

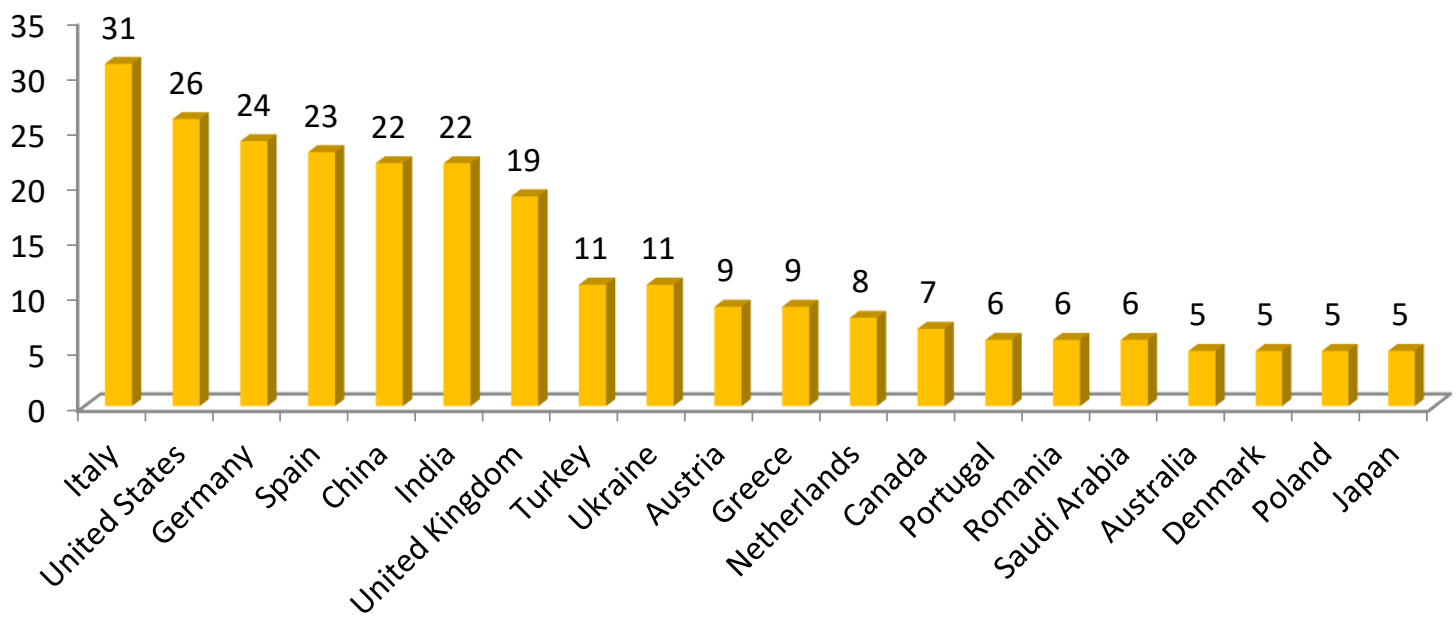

Figure 4. Top 20 Countries in Terms of Quantitative Dynamics of Publishing Activity, 20002019.

Source: developed by the authors based on (Scopus, 2020).

It should be noted that in some countries there is a direct relation between publishing and progress in implementing renewable energy sources and increasing energy efficiency. Namely, Italy is the leader in the number of publications on energy efficiency and renewable energy in the economic sphere. This country is among the top $10 \mathrm{EU}$ countries that at the beginning of 2017 implemented the" Plan 20-20-20" regulated by Directive 2009/28/EU of the European Parliament and of the Council as of 23 April 2009 on promoting the use of energy from 
renewable sources. At the beginning of 2017, Germany, Spain, Great Britain, Greece, Poland and Portugal failed to reach $20 \%$ of renewable energy sources in the structure of the energy complex (LIGAZAKON, 2009). Ukraine ranks 9th in the number of publications studying the selected problems in the field of economics - this is due to the Ukrainian scientists' participation in a large number of both domestic and foreign research programs and grants. Let us consider in more detail the cluster map of cooperation in the publishing field of the research domain presented in Figure 5.

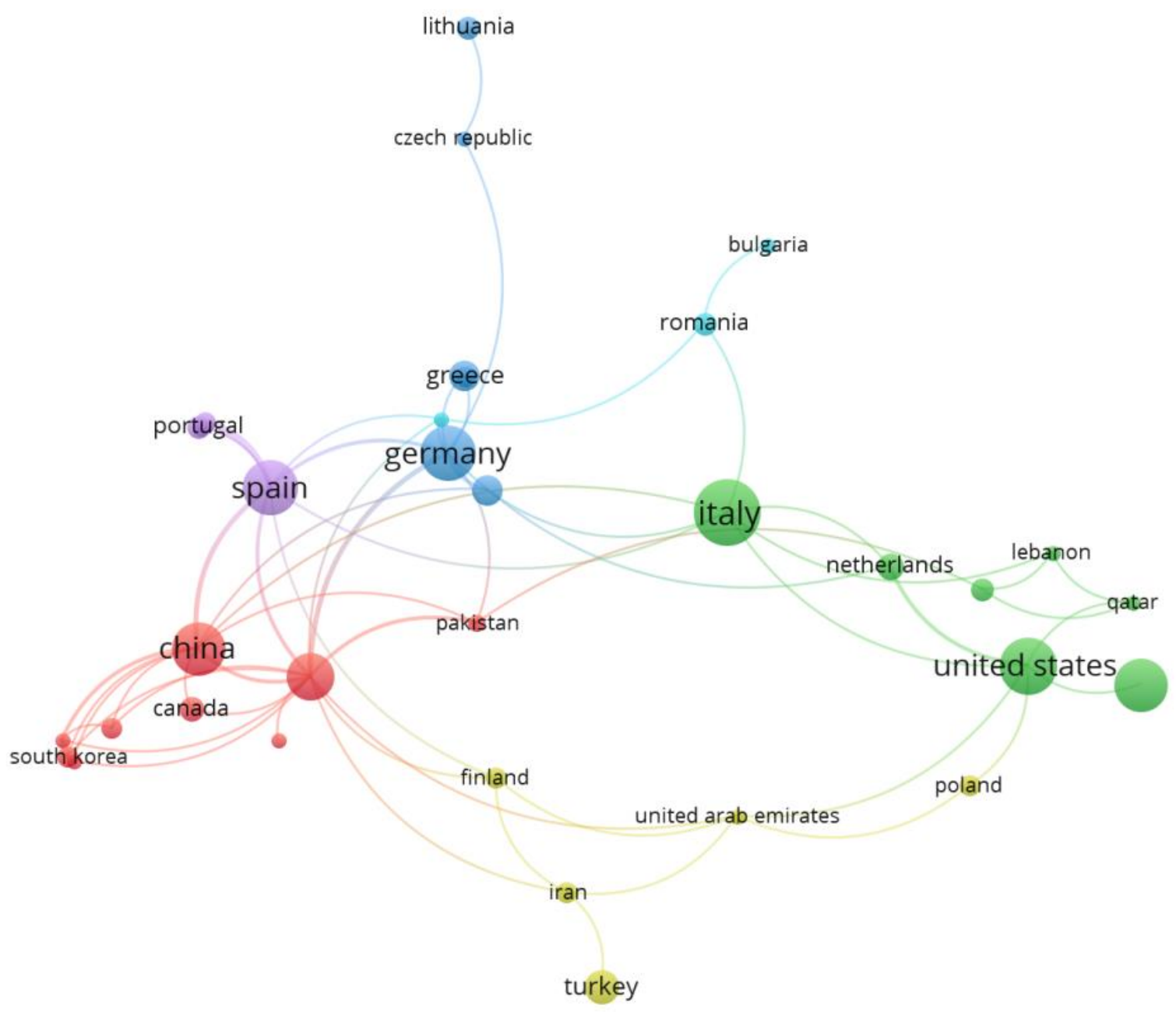

Figure 5. A Bibliometric Map of the Analysed Documents by Countries Published between 2000-2019.

Source: developed by the authors based on VOSviewer (2020).

Thus, we can distinguish six clusters of co-authorship. The red cluster is the largest (nine countries), uniting the countries of Europe, Asia and Africa. The green cluster includes eight countries (including the USA, Italy, and India). The blue cluster comprises only 6 EU countries. The yellow cluster covers the EU and the Middle East. However, the last two clusters of purple and blue colours show the co-authorship of the EU countries in the publications studied. 
From the researched data set, the first 10 articles with the largest number of citations were selected, and the studied publications were analysed (Table 1).

Table 1. Field-Weighted Citation Impact of Top-10 Cited Articles

\begin{tabular}{|c|c|c|c|c|c|}
\hline Rank & Journal & Title & $\begin{array}{c}\text { Year of } \\
\text { publicatio } \\
n\end{array}$ & Citations & $\begin{array}{l}\text { Field- } \\
\text { weighted } \\
\text { citation } \\
\text { impact }\end{array}$ \\
\hline 1 & $\begin{array}{l}\text { Energy, } \\
\text { Sustainability and } \\
\text { Society }\end{array}$ & $\begin{array}{l}\text { Hydrogen from Catalytic } \\
\text { Reforming of Biomass-Derived } \\
\text { Hydrocarbons in Liquid Water }\end{array}$ & 2002 & 1574 & 2,35 \\
\hline 2 & $\begin{array}{l}\text { American } \\
\text { Association for } \\
\text { the } \\
\text { Advancement of } \\
\text { Science }\end{array}$ & $\begin{array}{l}\text { Ethanol for a } \\
\text { Sustainable Energy Future }\end{array}$ & 2007 & 841 & 17,98 \\
\hline 3 & $\begin{array}{l}\text { Energy, } \\
\text { Sustainability and } \\
\text { Society }\end{array}$ & $\begin{array}{l}\text { A Molecular Molybdenum-Oxo } \\
\text { Catalyst for Generating Hydrogen } \\
\text { from Water }\end{array}$ & 2010 & 475 & 5,6 \\
\hline 4 & $\begin{array}{l}\text { Energy } \\
\text { Economics }\end{array}$ & $\begin{array}{l}\text { Energy Consumption and } \\
\text { Economic Growth: Evidence from } \\
\text { China at Both Aggregated and } \\
\text { Disaggregated Levels }\end{array}$ & 2008 & 348 & 8.44 \\
\hline 5 & $\begin{array}{l}\text { Computers, } \\
\text { Environment and } \\
\text { Urban Systems }\end{array}$ & $\begin{array}{l}\text { Quantifying Rooftop Solar } \\
\text { Photovoltaic Potential for Regional } \\
\text { Renewable Energy Policy }\end{array}$ & 2010 & 210 & 7.75 \\
\hline 6 & Technovation & $\begin{array}{l}\text { Hydrogen: The Energy Source for } \\
\text { the 21st Century }\end{array}$ & 2005 & 173 & 15.62 \\
\hline 7 & $\begin{array}{l}\text { Resources, } \\
\text { Conservation and } \\
\text { Recycling }\end{array}$ & $\begin{array}{l}\text { Minimising Carbon Footprint of } \\
\text { Regional Biomass Supply Chains }\end{array}$ & 2010 & 133 & 8.93 \\
\hline 8 & $\begin{array}{l}\text { Energy, } \\
\text { Sustainability and } \\
\text { Society }\end{array}$ & $\begin{array}{l}\text { Energy and Sustainable } \\
\text { Development in Nigeria: The Way } \\
\text { Forward }\end{array}$ & 2012 & 126 & 2.02 \\
\hline 9 & $\begin{array}{l}\text { Transportation } \\
\text { Research, Part D: } \\
\text { Transport and } \\
\text { Environment }\end{array}$ & $\begin{array}{l}\text { Training Urban Bus Drivers to } \\
\text { Promote Smart Driving: A Note on } \\
\text { a Greek Eco-Driving Pilot Program }\end{array}$ & 2007 & 107 & 1.09 \\
\hline 10 & $\begin{array}{l}\text { Proceedings of } \\
\text { the National } \\
\text { Academy of } \\
\text { Sciences of the } \\
\text { United States of } \\
\text { America }\end{array}$ & $\begin{array}{l}\text { Dependence of Hydropower } \\
\text { Energy Generation on Forests in } \\
\text { the Amazon Basin at Local and } \\
\text { Regional Scales }\end{array}$ & 2013 & 103 & 2.62 \\
\hline
\end{tabular}

Source: developed by the authors based on Scopus (2020).

Table 1 shows the top 10 items that explore the development and problems of implementation of renewable energy sources and their impact on energy efficiency in the 
economic sphere. The relevance and appropriateness of the article is assessed by several indicators, including the number of citations and Field-Weighted Citation Impact (FWCI) - the ratio of the total number of citations actually received to the total number of citations that can be expected based on the average value of the subject field.

The article with the largest number of citations (Cortright et al., 2002) reveals questions about alternative ways of hydrogen production not only from natural gas and oil, but also from renewable sources, including water and biomass. This is a very relevant study, because hydrogen is used in many areas of production: fuel (rocket fuel and coolant), food industry (food additive E949), chemical industry (in the production of soap, methanol, plastics), meteorology, etc.

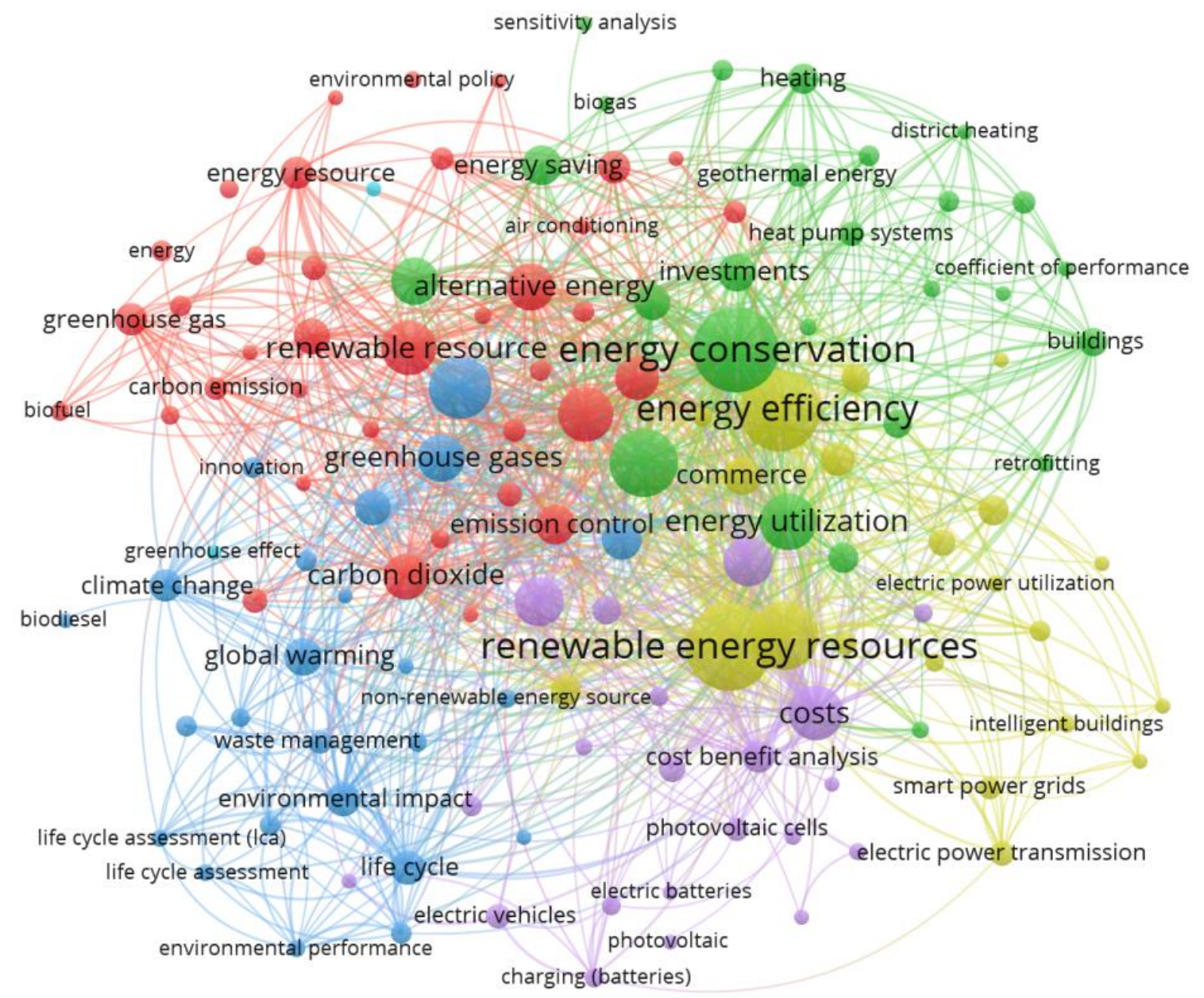

Figure 6. A Bibliometric Map of the Keywords in the Investigated Articles, 2000-2019. Source: developed by the authors based on VOSviewer (2020).

In second place in Table 1 is the article (Goldemberg, 2007) with the largest Field-Weighted Citation Impact, which explores issues related to producing ethanol from sugar cane, and its processing into environmentally friendly fuel, which is gaining popularity today. Ethanol is a 
substance in demand today and is widely used as a fuel in the chemical and food industries, in medicine, as well as in the production of perfumes, etc.

The research of thematic focus publications have been carried out by a visualization tool and analysis of clustering research VOSviewer, which allowed building a bibliographic map (Figure 6) of terms such as renewable energy, energy conservation and energy efficiency with a minimum number of occurrences in the title, keywords and abstract - 5 times.

As a result of constructing the terminological map, 5 clusters were identified, which united the key concepts in terms of thematic proximity. The main criteria for reading a bibliographic map are the size of the circle (characterizing the frequency of use of the term) and the length of the line (visualizes the strength of the connection between the concepts). Thus, the first cluster is red and includes 37 keywords, such as renewable resource, energy resource, carbon dioxide, energy market. This cluster was given a conventional name 'energy'.

In the "green" cluster there are 26 main terms, including renewable energy, energy conservation, energy saving, investments. Thus, the second cluster will be given a conventional name 'energy conservation'.

The third cluster has a conventional name 'sustainable development' and includes 26 keywords: life cycle, climate change, global warming, and is of blue colour.

The fourth cluster is yellow and is called 'renewable energy resources'. It includes 21 terms such as energy efficiency, renewable energy resources, commerce, energy management.

The purple cluster No 5 with a relevant name 'costs' includes 21 terms: costs, cost benefit analysis.

Considering all the clusters of the terminological map, we can conclude that the main terms under study - renewable energy and energy conservation - are interrelated, as evidenced by the lengths of the connecting lines, although they belong to different clusters. It is also necessary to note the sizes of circles which designate analysing terms: they are big enough compared to others, which gives understanding of the dynamics of their use in research.

\section{Conclusions}

Research of scientific results using the Scopus database provides great opportunities to present relevant and reliable information published by scientists around the world. Thus, such research is of great importance for further directions of developing scientific theories, views, etc. The bibliographic analysis consisted of such key basic concepts as "renewable energy sources" and "energy conservation" in the category "title, abstract, keywords." The results account for 896 scientific sources. The number of publications decreased after filtering according to the scientific areas: "Economics, Econometrics and Finance," "Multidisciplinary," "Business, Management and Accounting," "Social Sciences," and decreased to 337, which 
reveals the problems of energy efficiency and renewable energy sources in economic and social spheres. The tool for visualization and analysis of clustering the scientific research, VOSviewer, allowed achieving the goal set with the necessary degree of detail. Thus, the bibliometric analysis identified 5 main clusters, which visualized the results of the study and allowed proving the dependence of the main research terms: renewable sources and energy efficiency.

Thus, from the above material we can draw the following conclusions.

First, according to the terminological map, the relation between the terms 'renewable energy,' 'energy saving' and 'energy efficiency' is strong and dynamic. Accordingly, these three main terms have approximately the same time of occurrence in the scientific research. Energy saving is based on two main factors:

1) introduction and use of renewable energy sources;

2) energy efficiency of equipment that supplies and produces energy, as well as the facilities themselves, which must retain and receive energy from the environment as much as possible.

Secondly, during the study of publications, new directions in producing alternative energy sources in transition to a carbon-neutral economy were identified.

Thirdly, it could be forecasted that in the process of studying the field of green deal policy research, the number of publications will increase as a new cycle in developing a neutral carbon economy is about to begin.

\section{Formatting of Funding Sources}

This research was funded by the grant from the Ministry of Education and Science of Ukraine (0120U102002) and by the grant from the National Research Foundation of Ukraine "Stochastic Modelling of Road Map for Harmonizing National and European Standards for Energy Market Regulation in the Transition to a Circular and Carbon-Free Economy" (ID 2020.02/0231).

\section{References}

Akinwale, Y.O., Ogundari, I.O., Ilevbare, O.E., \& Adepoju, A.O. (2014). A Descriptive Analysis of Public Understanding and Attitudes of Renewable Energy Resources towards Energy Access and Development in Nigeria. International Journal of Energy Economics and Policy, 4(4), 636-646.

Bigerna, S., Bollino, C. A., \& Micheli, S. (2019) Green Electricity Investments: Environmental Target and the Optimal Subsidy. European Journal of Operational Research, 279(2), 635-644. 
Bilan, Y., Raišienè, A. G., Vasilyeva, T., Lyulyov, O., \& Pimonenko, T. (2019). Public Governance Efficiency and Macroeconomic Stability: Examining Convergence of Social and Political Determinants. Public Policy and Administration, 18(2), 241-255. https://doi.org/10.13165/VPA-19-18-2-05

Bogachov, S., Kwilinski, A., Miethlich, B., Bartosova, V., Gurnak, A. (2020). Artificial Intelligence Components and Fuzzy Regulators in Entrepreneurship Development. Entrepreneurship and Sustainability Issues, 8(2), 487-499. http://doi.org/10.9770/jesi.2020.8.2(29)

Boiko, V., Kwilinski, A., Misiuk, M., \& Boiko, L. (2019). Competitive Advantages of Wholesale Markets of Agricultural Products as a Type of Entrepreneurial Activity: The Experience of Ukraine and Poland. Economic Annals-XXI, 175(1-2), 68-72. https://doi.org/10.21003/ea.V175-12

Cebula, J., \& Pimonenko, T. (2015). Comparison Financing Conditions of the Development Biogas Sector in Poland and Ukraine. International Journal of Ecology and Development, 30(2), 20-30.

Chel, A. (2009) Building Integrated Renewable Energy Technologies: Embodied Energy, Economic Analysis and Potential of $\mathrm{CO}_{2}$ Emission Mitigation. International Journal of Energy, Environment and Economics, 17(2-3), 185-210.

Chygryn, O., Pimonenko, T., Luylyov, O., \& Goncharova, A. (2018). Green Bonds like the Incentive Instrument for Cleaner Production at the Government and Corporate Levels Experience from EU to Ukraine. Journal of Advanced Research in Management, 9(7), 1443-1456.

Chygryn, O.Yu. (2018) Green Consumption: Preconditions and Prospects of Promotion. Bulletin of Sumy State University. Economics Series, 3, 82-86. https://doi.org/10.21272 / 1817-9215.2018.3-12.

Cortright, R. D., Davda, R. R., \& Dumesic, J. A. (2002) Hydrogen from Catalytic Reforming of BiomassDerived Hydrocarbons Inliquid Water. Nature, 418, 964-967.

Dalevska, N., Khobta, V., Kwilinski, A., \& Kravchenko, S. (2019). A Model for Estimating Social and Economic Indicators of Sustainable Development. Entrepreneurship and Sustainability Issues, 6(4), 1839-1860. https://doi.org/10.9770/jesi.2019.6.4(21)

Dementyev, V.V., \& Kwilinski, A. (2020). Institutsionalnaya sostavlyayuschaya izderzhek proizvodstva [An Institutional Component of Production Costs]. Journal of Institutional Studies, 12(1), 100-116. https://doi.org/10.17835/2076-6297.2020.12.1.100-116

Dkhili, H. (2018). Environmental Performance and Institutions Quality: Evidence from Developed and Developing Countries. Marketing and Management of Innovations, 3, 333-344.

Drozdz, W., Miskiewicz, R., Pokrzywniak, J., \& Elzanowski, F. (2019). Urban Electromobility in the Context of Industry 4.0. Torun: Wydawnictwo Adam Marszalek. 
Drozdz, W., Marszalek-Kawa, J., Miskiewicz, R., \& Szczepanska-Waszczyna, K. (2020). Digital Economy in the Contemporary World. Torun: Wydawnictwo Adam Marszalek.

Dzwigol, H. (2019a). The Concept of the System Approach of the Enterprise Restructuring Process. Virtual Economics, 2(4), 46-70. https://doi.org/10.34021/ve.2019.02.04(3)

Dzwigol, H. (2019b). Research Methods and Techniques in New Management Trends: Research Results. Virtual Economics, 2(1), 31-48. https://doi.org/10.34021/ve.2019.02.01(2)

Dzwigol, H. (2020a). Innovation in Marketing Research: Quantitative and Qualitative Analysis. Marketing and Management of Innovations, 1, 128-135. http://doi.org/10.21272/mmi.2020.1-10

Dzwigol, H. (2020b). Methodological and Empirical Platform of Triangulation in Strategic Management. Academy of Strategic Management Journal, 19(4), 1-8.

Dźwigoł, H. (2020c). Interim Management as a New Approach to the Company Management. Review of Business and Economics Studies, 8(1), 20-26. https://doi.org/10.26794/2308-944X-2020-8-1-2026

Dzwigol, H., \& Wolniak, R. (2018). Controlling w procesie zarządzania chemicznym przedsiębiorstwem produkcyjnym [Controlling in the Management Process of a Chemical Industry Production Company]. Przemys/ Chemiczny, 97(7), 1114-1116. https://doi.org/10.15199/62.2018.7.15

Dzwigol, H., \& Dźwigoł-Barosz, M. (2018). Scientific Research Methodology in Management Sciences. Financial and Credit Activity: Problems of Theory and Practice, 2(25), 424-437. https://doi.org/10.18371/fcaptp.v2i25.136508

Dzwigol, H., \& Dzwigol-Barosz, M. (2020). Sustainable Development of the Company on the Basis of Expert Assessment of the Investment Strategy. Academy of Strategic Management Journal, 19(5), 1-7.

Dzwigol, H., Shcherbak, S., Semikina, M., Vinichenko, O., \& Vasiuta, V. (2019a). Formation of Strategic Change Management System at an Enterprise. Academy of Strategic Management Journal, 18(SI1), 1-8.

Dzwigol, H., Aleinikova, O., Umanska, Y., Shmygol, N., \& Pushak, Y. (2019b). An Entrepreneurship Model for Assessing the Investment Attractiveness of Regions. Journal of Entrepreneurship Education, 22(1S), 1-7.

Dzwigoł, H., Dzwigoł-Barosz, M., Zhyvko, Z., Miskiewicz, R., \& Pushak, H. (2019c). Evaluation of the Energy Security as a Component of National Security of the Country. Journal of Security and Sustainability Issues, 8(3), 307-317. http://doi.org/10.9770/jssi.2019.8.3(2) 
Dzwigol, H., Dźwigoł-Barosz, M., \& Kwilinski, A. (2020d). Formation of Global Competitive Enterprise Environment Based on Industry 4.0 Concept. International Journal of Entrepreneurship, 24(1), 1-5.

Dzwigol, H., Dzwigol-Barosz, M., Miskiewicz, R., \& Kwilinski, A. (2020). Manager Competency Assessment Model in the Conditions of Industry 4.0. Entrepreneurship and Sustainability Issues, 7(4), 2630-2644. https://doi.org/10.9770/jesi.2020.7.4(5)

Furmaniak, S., Gauden, P.A., Patrykiejew, A., Miśkiewicz, R., \& Kowalczyk, P. (2018). Carbon Nanohorns as Reaction Nanochambers - a Systematic Monte Carlo Study. Scientific Reports, 15407. https://doi.org/10.1038/s41598-018-33725-z

Furmaniak, S., Gauden, P.A., Patrykiejew, A., Miskiewicz, R., \& Kowalczyk, P. (2019a). The Effects of Confinement in Pores Built of Folded Graphene Sheets on the Equilibrium of Nitrogen Monoxide Dimerisation Reaction. Journal of Physics Condensed Matter, 31(13), 135001, 1-12. https://doi.org/10.1088/1361-648X/aaffb3

Furmaniak, S., Gauden, P.A., Patrykiejew, A., Szymański, G., Miśkiewicz, R., \& Kowalczyk, P. (2019b). In Silico Study on the Effects of Carbonyl Groups on Chemical Equilibrium of Reactions with a Polar Product Occurring under Confinement in Pores of Activated Carbons. Chemical Engineering Communications, 1-12. https://doi.org/10.1080/00986445.2019.1700115

John-Felix, K. A. (2001). Renewable Energy Resources and Technologies in Nigeria: Present Situation, Future Prospects and Policy Framework. Mitigation and Adaptation Strategies for Global Change, 6, 155-182.

Goldemberg, J. (2007). Ethanol for a Sustainable Energy. Future Science, 315(5813), 808-810.

Kondratenko, V., Okopnyk, O., Ziganto, L., \& Kwilinski, A. (2020). Innovation Development of Public Administration: Management and Legislation Features. Marketing and Management of Innovations, 1, 87-94. https://doi.org/10.21272/mmi.2020.1-06

Kharazishvili, Y., Kwilinski, A., Grishnova, O., \& Dzwigol, H. (2020). Social Safety of Society for Developing Countries to Meet Sustainable Development Standards: Indicators, Level, Strategic Benchmarks (with Calculations Based on the Case Study of Ukraine). Sustainability, 12(21), 8953. https://doi.org/10.3390/su12218953

Kuzior, A., Kwilinski, A., \& Tkachenko, V. (2019). Sustainable Development of Organizations Based on the Combinatorial Model of Artificial Intelligence. Entrepreneurship and Sustainability, 7(2), 13531376. http://doi.org/10.9770/jesi.2019.7.2(39)

Kwilinski, A. (2017). Development of Industrial Enterprise in the Conditions of Formation of Information Economics. Thai Science Review, Autumn 2017, 85-90. https://doi.org/10.5281/zenodo.1414236 
Kwilinski, A. (2018a). Mechanism of Formation of Industrial Enterprise Development Strategy in the Information Economy. Virtual Economics, 1(1), 7-25. https://doi.org/10.34021/ve.2018.01.01(1)

Kwilinski, A. (2018b). Mechanism of Modernization of Industrial Sphere of Industrial Enterprise in Accordance with Requirements of the Information Economy. Marketing and Management of Innovations, 4, 116-128. http://doi.org/10.21272/mmi.2018.4-11

Kwilinski, A. (2018c). Mechanism for Assessing the Competitiveness of an Industrial Enterprise in the Information Economy. Research Papers in Economics and Finance, 3(1), 7-16. https://doi.org/10.18559/ref.2018.1.1

Kwilinski, A. (2018d). Trends of Development of the Information Economy of Ukraine in the Context of Ensuring the Communicative Component of Industrial Enterprises. Economics and Management, 1(77), 64-70.

Kwilinski, A. (2019). Implementation of Blockchain Technology in Accounting Sphere. Academy of Accounting and Financial Studies Journal, 23(SI2), 1-6.

Kwilinski, A., Tkachenko, V., \& Kuzior, A. (2019a). Transparent Cognitive Technologies to Ensure Sustainable Society Development. Journal of Security and Sustainability Issues, 9(2), 561-570 http://doi.org/10.9770/jssi.2019.9.2(15)

Kwilinski, A., Drobyazko, S., \& Derevyanko, B. (2019b). Synergetic and Value Effects in Corporate Mergers and Acquisitions of International Companies. In Khalid S. Soliman (Ed.), Proceedings of the 34th International Business Information Management Association Conference (IBIMA) 13-14 November 2019. Vision 2025: Education Excellence and Management of Innovations through Sustainable Economic Competitive Advantage in 2019 (pp. 9467-9471). Madrid, Spain: IBIMA Publishing.

Kwilinski, A., Dalevska, N., Kravchenko, S., Hroznyi, I., Kovalenko, I. (2019c). Formation of the Entrepreneurship Model of E-Business in the Context of the Introduction of Information and Communication Technologies. Journal of Entrepreneurship Education, 22(SI1), 1528-2651-22-S1337: 1-7.

Kwilinski, A., Ruzhytskyi, I., Patlachuk, V., Patlachuk, O., \& Kaminska, B. (2019d). Environmental Taxes as a Condition of Business Responsibility in the Conditions of Sustainable Development. Journal of Legal, Ethical and Regulatory Issues, 22(SI2) 1544-0044-22-SI-2-354: 1-6.

Kwilinski, A., Volynets, R., Berdnik, I., Holovko, M., \& Berzin, P. (2019e). E-Commerce: Concept and Legal Regulation in Modern Economic Conditions. Journal of Legal, Ethical and Regulatory Issues, 22(SI2), 1544-0044-22-SI-2-357: 1-6. 
Kwilinski, A., Dzwigol, H., \& Dementyev, V. (2019f). Transnational Corporations as Entities of International Entrepreneurship. International Journal of Entrepreneurship, 23(SI4), 1-6.

Kwilinski, A., Pajak, K., Halachenko, O., Vasylchak, S., Pushak, Ya., \& Kuzior, P. (2019g). Marketing Tools for Improving Enterprise Performance in the Context of Social and Economic Security of the State: Innovative Approaches to Assessment. Marketing and Management of Innovations, 4, 172-181. http://doi.org/10.21272/mmi.2019.4-14

Kwilinski, A., \& Kuzior, A. (2020). Cognitive Technologies in the Management and Formation of Directions of the Priority Development of Industrial Enterprises. Management Systems in Production Engineering, 28(2), 119-123. http://doi.org/10.1515/mspe-2019-0020

Kwilinski, A., Vyshnevskyi, O., \& Dzwigol, H. (2020a). Digitalization of the EU Economies and People at Risk of Poverty or Social Exclusion. Journal of Risk and Financial Management, 13(7), 142. https://doi.org/10.3390/jrfm13070142

Kwilinski, A., Zaloznova, Y., Trushkina, N., \& Rynkevych, N. (2020b). Organizational and Methodological Support for Ukrainian Coal Enterprises Marketing Activity Improvement. E3S Web of Conferences, 168, 00031. https://doi.org/10.1051/e3sconf/202016800031

Kwilinski, A., Dielini, M., Mazuryk, O., Filippov, V., \& Kitseliuk, V. (2020c). System Constructs for the Investment Security of a Country. Journal of Security and Sustainability Issues, 10(1), 345-358. https://doi.org/10.9770/jssi.2020.10.1(25)

Kwilinski, A., Shteingauz, D., \& Maslov, V. (2020). Financial and Credit Instruments for Ensuring Effective Functioning of the Residential Real Estate Market. Financial and Credit Activities: Problems of Theory and Practice. 3(34), 133-140. Retrieved from https://fkd.ubs.edu.ua/index.php/fkd/article/view/3023

Kyrylov, Y., Hranovska, V., Boiko, V., Kwilinski, A., \& Boiko, L. (2020). International Tourism Development in the Context of Increasing Globalization Risks: On the Example of Ukraine's Integration into the Global Tourism Industry. Journal of Risk and Financial Management, 13(12), 303. https://doi.org/10.3390/jrfm13120303

Lam, H. L., Varbanov, P., \& Klemeš, J. (2010) Minimising Carbon Footprint of Regional Biomass Supply Chains. Resources, Conservation and Recycling, 54(5), 303-309.

Lakhno, V., Malyukov, V., Bochulia, T., Hipters, Z., Kwilinski, A., \& Tomashevska, O. (2018). Model of Managing of the Procedure of Mutual Financial Investing in Information Technologies and Smart City Systems. International Journal of Civil Engineering and Technology, 9(8), 1802-1812.

LIGAZAKON. (2009). Directive 2009/28/EU of the European Parliament and of the Council of 23 April 
2009 on the Promotion of the Use of Energy from Renewable Sources and Amending and Subsequently Repealing Directives 2001/77/EU and 2003/30/EU (2009). Retrieved from https://ips.ligazakon.net/document/MU09267

Lyulyov, O. V., \& Pimonenko, T. V. (2017). Lotka-Volterra Model as an Instrument of the Investment and Innovative Processes Stability Analysis. Marketing and Management of Innovations, 1, 159169.

Lyulyov, O., \& Shvindina, H. (2017). Stabilisation Pentagon Model: Application in the Management at Macro- and Micro-Levels. Problems and Perspectives in Management, 15(3), 42-52. https://doi.org/10.21511/ppm.15(3).2017.04

Lyulyov, O., Chortok, Y., Pimonenko, T., \& Borovik, O. (2015). Ecological and Economic Evaluation of Transport System Functioning According to the Territory Sustainable Development. International Journal of Ecology and Development, 30(3), 1-10.

Matsenko, O., Chigrin, E., Taranovsky, V., \& Dolgodush, A. (2011). Socio-Ecological-Economic Challenges of Water Supply in Ukraine. Mechanism of Economic Regulation, 4, 264-271.

Miskiewicz, R. (2017a). Knowledge in the Process of Enterprise Acquisition. Progress in Economic Sciences, 4, 415-432. https://doi.org/10.14595/PES/04/029

Miskiewicz, R. (2017b). Knowledge Transfer in Merger and Acquisition Processes in the Metallurgical Industry. Warsaw: PWN.

Miskiewicz, R. (2018). The Importance of Knowledge Transfer on the Energy Market. Polityka Energetyczna, 21(2), 49-62. http://dx.doi.org/10.24425\%2F122774

Miskiewicz, R. (2019). Challenges Facing Management Practice in the Light of Industry 4.0: The Example of Poland. Virtual Economics, 2(2), 37-47. https://doi.org/10.34021/ve.2019.02.02(2)

Miskiewicz, R. (2020). Internet of Things in Marketing: Bibliometric Analysis. Marketing and Management of Innovations, 3, 371-381. http://doi.org/10.21272/mmi.2020.3-27

Miskiewicz, R. (2020a). Efficiency of Electricity Production Technology from Post-Process Gas Heat: Ecological, Economic and Social Benefits. Energies, 13(22), 6106. https://doi.org/10.3390/en13226106

Miśkiewicz, R, \& Wolniak, R. (2020b). Practical Application of the Industry 4.0 Concept in a Steel Company. Sustainability, 12(14), 5776. https://doi.org/10.3390/su12145776

Oyedepo, S.O. (2012). Energy and Sustainable Development in Nigeria: The Way Forward. Energy, Sustainability and Society, 2, 1-17. 
Palienko, M., \& Lyulyov, O. (2018). The Impact of Social Factors on Macroeconomic Stability: Empirical Evidence for Ukraine and European Union Countries. SocioEconomic Challenges, 2(1), 103-116.

Pająk, K., Kamińska, B., \& Kvilinskyi, O. (2016). Modern Trends of Financial Sector Development under the Virtual Regionalization Conditions. Financial and Credit Activity: Problems of Theory and Practice, 2(21), 204-217. https://doi.org/10.18371/fcaptp.v2i21.91052

Pająk, K., Kvilinskyi, O., Fasiecka, O., \& Miskiewicz, R. (2017). Energy Security in Regional Policy in Wielkopolska Region of Poland. Economics and Environment, 2(61), 122-138.

Pimonenko, T., Chyhryn, O., \& Liulov, O. (2018). Green Entrepreneurship as an Integral Part of the National Economy Convergence. National Security \& Innovation Activities: Methodology, Policy and Practice: A monograph. Sumy, Ukraine: SSU.

Pimonenko, T., \& Lyulyov, O. (2018). Marketing Instruments to Promote Green Investment: Declining Greenwashing. Economic Space, 140, 204-213. Retrieved from http://nbuv.gov.ua/UJRN/ecpros_2018_140_18

Pimonenko, T., Lyulyov, O., Chygryn, O., \& Palienko, M. (2018). Environmental Performance Index: Relation between Social and Economic Welfare of the Countries. Environmental Economics, 9(3), 1-11. http://dx.doi.org/10.21511/ee.09(3).2018.01

Prokopenko, O., Chayen, S., Cebula, J., \& Pimonenko, T. (2017). Wind Energy in Israel, Poland and Ukraine: Features and Opportunities. International Journal of Ecology and Development, 32(1), 98107.

Prokopenko, O., \& Miśkiewicz, R. (2020). Perception of "Green Shipping" in the Contemporary Conditions. Entrepreneurship and Sustainability Issues, 8(2), 269-284. https://doi.org/10.9770/jesi.2020.8.2(16)

Saługa, P.W., Szczepańska-Woszczyna, K., Miśkiewicz, R., \& Chłąd, M. (2020). Cost of Equity of CoalFired Power Generation Projects in Poland: Its Importance for the Management of DecisionMaking Process. Energies, 13(18), 4833.https://doi.org/10.3390/en13184833

Savchenko, T., Basiurkina, N., Rodina, O., \& Kwilinski, A. (2019). Improvement of the Assessment Methods of Product Competitiveness of the Specialized Poultry Enterprises. Management Theory and Studies for Rural Business and Infrastructure Development, 41(1), 43-61. https://doi.org/10.15544/mts.2019.05

Scopus. (2020). Retrieved from https://www.scopus.com

Sineviciene, L., Sotnyk, I., \& Kubatko, O. (2017). Determinants of Energy Efficiency and Energy Consumption of Eastern Europe Post-Communist Economies. Energy \& Environment, 8, 870-884. 
The European Commission. (2020). Retrieved from https://ec.europa.eu/info/index_en

Tkachenko, V., Kwilinski, A., Korystin, O., Svyrydiuk, N., \& Tkachenko, I. (2019a). Assessment of Information Technologies Influence on Financial Security of Economy. Journal of Security and Sustainability, 8(3), 375-385. http://doi.org/10.9770/jssi.2019.8.3(7)

Tkachenko, V., Kwilinski, A., Klymchuk, M., \& Tkachenko, I. (2019b). The Economic-Mathematical Development of Buildings Construction Model Optimization on the Basis of Digital Economy. Management Systems in Production Engineering, 27(2), 119-123. http://doi.org/10.1515/mspe2019-0020

Tkachenko, V., Kwilinski, A., Tkachenko, I., \& Puzyrova, P. (2019c). Theoretical and Methodical Approaches to the Definition of Marketing Risks Management Concept at Industrial Enterprises. Marketing and Management of Innovations, 2, 228-238. http://doi.org/10.21272/mmi.2019.2-20

Tkachenko, V., Kwilinski, A., Kaminska, B., Tkachenko, I., \& Puzyrova, P. (2019d). Development and Effectiveness of Financial Potential Management of Enterprises in Modern Conditions. Financial and Credit Activity: Problems of Theory and Practice, 3(30), 85-94. https://doi.org/10.18371/fcaptp.v3i30.179513

Tkachenko, V., Kuzior, A., \& Kwilinski, A. (2019e). Introduction of Artificial Intelligence Tools into the Training Methods of Entrepreneurship Activities. Journal of Entrepreneurship Education, 22(6), 110.

Vanickova, R. (2020). Innovation Corporate Energy Management: Efficiency of Green Investment. Marketing and Management of Innovations, 2, 56-67. http://doi.org/10.21272/mmi.2020.2-04

Verkhovna Rada of Ukraine. (2006). Green Paper of the Commission of the European Communities: European Strategy for Sustainable, Competitive and Secure Energy. Retrieved from https://zakon.rada.gov.ua/laws/show/994_713\#Text

Verkhovna Rada of Ukraine (2016). Vidomosti Verkhovnoi Rady, 2016, N 35, p. 595 [Law of Ukraine On Ratification of the Paris Agreement]. Retrieved from https://zakon.rada.gov.ua/laws/show/146919\#n2 [in Ukrainian].

VOSviewer. (2020). Retrieved from https://www.vosviewer.com/

Wiginton, L.K., Nguyen, H.T., \& Pearce, J.M. (2010). Quantifying Rooftop Solar Photovoltaic Potential for Regional Renewable Energy Policy. Computers, Environment and Urban Systems, 34(4), 345357.

Yelnikova, Y., \& Miskiewicz, R. (2020). Implementation Mechanism of Impact Investing in the PostConflict Regions. Financial Markets. Institutions and Risks, 4(3), 53-65. 
https://doi.org/10.21272/fmir.4(3).53-62.2020

Yevdokimov, Y., Chygryn, O., Pimonenko, T., \& Lyulyov, O. (2018). Biogas as an Alternative Energy Resource for Ukrainian Companies: EU Experience. Innovative Marketing, 14(2), 7-15.

Ziabina, E. A. (2016). Theoretical Aspects of the Formation of a 'Green' Economy in the Context of Sustainable Development. Mechanism of Economic Regulation, 3, 116-121. 